\title{
Seasonal Dynamics in Forest Soil Seed Banks along an Elevational Gradient in the Rocky Mountainous Area of North China
}

\author{
Chengshu Xin ${ }^{1,2}$, Jianyong Wang ${ }^{3}$, Jianying Yang ${ }^{1,2}$ and Tingning Zhao ${ }^{1,2, *}$ \\ 1 School of Soil and Water Conservation, Beijing Forestry University, Beijing 100083, China; \\ xinchengshu@hotmail.com (C.X.); jyyang@bjfu.edu.cn (J.Y.) \\ 2 Key Laboratory of State Forestry Administration on Soil and Water Conservation, Beijing Forestry University, \\ Beijing 100083, China \\ 3 Laboratory of Systematic Evolution and Biogeography of Woody Plants, Beijing Forestry University, \\ Beijing 100083, China; wangjy6153@foxmail.com \\ * Correspondence: zhtning@bjfu.edu.cn; Tel.: +86-10-6233-8154
}

Citation: Xin, C.; Wang, J.; Yang, J.; Zhao, T. Seasonal Dynamics in Forest Soil Seed Banks along an Elevational Gradient in the Rocky Mountainous Area of North China. Forests 2021, 12, 1318. https://doi.org/10.3390/ f12101318

Academic Editor: Bogdan Jaroszewicz

Received: 3 August 2021

Accepted: 23 September 2021

Published: 27 September 2021

Publisher's Note: MDPI stays neutral with regard to jurisdictional claims in published maps and institutional affiliations.

Copyright: (C) 2021 by the authors. Licensee MDPI, Basel, Switzerland. This article is an open access article distributed under the terms and conditions of the Creative Commons Attribution (CC BY) license (https:/ / creativecommons.org/licenses/by/ $4.0 /)$.

\begin{abstract}
Although exploring soil seed bank characteristics and dynamics is conducive to plant diversity protection and restoration, few investigations have been undertaken in the rocky mountainous area of North China. To address this research gap, qualitative and quantitative changes in soil seed bank characteristics over different seasons and elevations as well as potential causes for differences were examined, using data from 25 secondary forest communities in the Songshan area of Beijing, China. Nonmetric multidimensional scaling (NMDS) was used to test the similarity of the composition of the seed bank and the understory vegetation during different seasons. In addition, the structural equation model (SEM) was used to explore the direct and indirect effects on seed bank density. The results indicate that abundance and species richness decreased with elevation, with seed density reaching its maximum and minimum levels in April and July at all elevation levels, respectively. In terms of species composition, the understory vegetation was significantly different from the seed bank, and the proportion of herbaceous plants species in the seed bank was higher. Soil total nitrogen, available phosphorus and available potassium all changed with elevation, directly or indirectly affecting seed bank density. The application of seed banks present in topsoil from the rocky mountainous area of North China can be potentially used for ecological restoration. It is important, however, to consider the elevation and the season related to the removal of the topsoil to achieve optimal effects.
\end{abstract}

Keywords: soil seed bank; characteristics dynamic; vegetation restoration; rocky mountainous area

\section{Introduction}

The rocky mountainous area of North China is a typical, ecologically fragile area, characterized by sparse vegetation and poor soil with a high concentration of gravel [1,2]. This area has suffered from long-term land degradation, resulting in an urgent need for vegetation maintenance and restoration [3]. Vegetation maintenance and restoration in degraded areas are also one of the goals of the Three North Shelterbelt Project, commonly known as the Great Green Wall [4]. The study area, situated near the competition zone for the 2022 Beijing Winter Olympics, has a high demand for environmental protection. As this area contains the main water source for the Beijing urban area, maintaining the forest ecosystem in the local and surrounding areas is, therefore, very important.

The sum of surviving seeds that is present in soil and on its surface is defined as the soil seed bank [5]. As a refuge for seeds, the soil environment can prolong the activity of seeds and protect them from negative disturbances $[6,7]$. When growth conditions are met, seeds in the seed bank will germinate to supplement or rebuild the surface vegetation community [8]. The seed bank is, therefore, important to reduce the risk of plant 
population extinction and to ensure species continuation [9,10], thereby maintaining plant community diversity [11]. The feasibility of using topsoil and its seedbank as a vegetation restoration material was previously highlighted [12-15]. The seed bank present in the topsoil provides a seed source for vegetation restoration, conducive to the establishment of indigenous plants in the local environment [16]. Therefore, revealing the dynamic changes in soil seed bank characteristics and their affecting factors has both theoretical and practical applications.

Investigations examining factors affecting seed banks were previously undertaken. As environmental factors vary with elevation, the influence that elevation has on soil seed bank characteristics is, therefore, a complex issue. [17]. Conflicting results have been presented, proposing that an increase in elevation results in a decrease in soil seeds $[17,18]$, and vice versa $[8,19]$. Low temperatures caused by high elevation may be conducive to preserving soil seeds, coupled with few predators and fungal diversity [20] as well as a lowering of the embryonic metabolic rate of seeds [21]. On the other hand, harsh environments in high elevation areas may cause a decrease in vegetation abundance and seed yield [22]. Soil total nitrogen (TN), available phosphorus (AP), available potassium (AK) and $\mathrm{pH}$ values could also have an important impact on the seed bank and aboveground vegetation [23], possibly being indirectly driven by elevation [24].

The season also has an essential and intricate impact on the seed bank. Previous studies have shown that the seed bank density gradually peaks within a period of time after the plant seeds mature, and the lowest seed bank density occurs before the seeds disperse $[25,26]$. In this process, variations in different environmental factors due to seasonal changes shape the dynamics of the seed bank over the year. In general, the majority of seeds are shed at the end of autumn, and they germinate in the spring [27], resulting in a peak in seed abundance any time between November and the following May [28]. In the summer, an increase in soil microorganism activity and predators may also lead to a decrease in the seed bank density [27]. It was also reported that seed bank changes derive from the alternation of rain and drought, and the arrival of the dry season leads to a decline in the seed bank $[9,29]$. Therefore, we aim to identify variations in the characteristics of a local soil seed bank, whilst verifying or optimizing previous conclusions.

The aboveground vegetation community can affect the composition of the seed bank [30-32], and seed bank density tends to increase in areas with a higher vegetation abundance [33]. However, the composition of the seed bank does not necessarily represent that of the plant community since many understory species may not appear in the soil seed bank and vice versa [34]. Generally, similarity in forest ecosystems is lower than that of wastelands, grasslands and wetlands, and this low similarity may further decrease with succession $[35,36]$. While species composition of the seed bank may renew with this process [37], some plants that are extinct in the local area could potentially return [38]. Although current research on similarities between the seed bank composition and understory vegetation predominantly focuses on different stages or types of plant communities, few investigations examine dynamics among seasons. Therefore, exploring the relationship between seed banks and understory vegetation during different seasons is crucial to understanding their relevance in ecological restoration [36].

On the whole, although there have been extensive studies and some general patterns on the relationship between seed banks and influencing factors, their backgrounds are varied, and it is difficult to apply the previous conclusions to our research area. Currently, studies examining characteristics and influencing factors of forest seed banks in the rocky mountainous area of North China are still scarce. In particular, the role of seed banks in natural secondary forests in this area is still unclear. In this study, therefore, we investigated plant communities in 25 plots and collected soil samples during three consecutive seasons in the rocky mountainous area of North China. Results from this investigation will enable the following specific aspects to be examined: (1) the characteristics of the soil seed bank that respond to different elevations and seasons; (2) the variations in the relationship between the soil seed bank and understory vegetation; and (3) the influence of 
soil environment changes on seed banks driven by elevation. Furthermore, findings from our study will also contribute to estimating the ecological restoration potential of seed banks and understanding the distribution rules of forest seed banks in temperate regions, as well as providing a basis for the standardization of topsoil utilization in the local area.

\section{Materials and Methods}

\subsection{Study Site}

This study was conducted in the Songshan Nature Reserve $\left(40^{\circ} 29^{\prime} 9^{\prime \prime}-40^{\circ} 33^{\prime} 35^{\prime \prime} \mathrm{N}\right.$, $115^{\circ} 43^{\prime} 44^{\prime \prime}-115^{\circ} 50^{\prime} 22^{\prime \prime}$ E) northwest of Beijing, a typical rocky mountainous area of North China. The total area of the nature reserve is $4671 \mathrm{ha}$, having an elevation of $627-2984 \mathrm{~m}$. The study site has a typical temperate continental climate with an average annual temperature of $8.5{ }^{\circ} \mathrm{C}$ and annual precipitation of $493 \mathrm{~mm}$. This area is a warm-temperate mountain ecosystem with a well-preserved natural ecological environment in North China. It was reported that this area has 721 species of wild plants in 382 genera belonging to 92 families [39]. Natural secondary forests are distributed below an elevation of $1800 \mathrm{~m}$, and the soil type is mainly brown loam. The main tree species in this area include Quercus mongolica, Populus davidiana, Fraxinus rhynchophylla and Betula dahurica.

\subsection{Data Collection}

Since this study examined forest vegetation and soil seed banks, sample sites were only situated at elevations below $1800 \mathrm{~m}$; above this elevation, forest vegetation was rarely present. The plant community in forests with different elevations was investigated during the peak period of plant growth in August 2019. According to information provided by the reserve and on-site surveys, five sample plots $(20 \times 20 \mathrm{~m})$ were established for attitude gradients of 800,1000, 1200, 1400, and $1600 \mathrm{~m}$, resulting in 25 sample plots in total (Table 1, Figure 1). In each sample plot, the tree height and diameter at breast height (DBH) above $3 \mathrm{~cm}$ were recorded. Using the five-point sampling method, five $2 \mathrm{~m} \times 2 \mathrm{~m}$ plots were established to investigate the understory vegetation. Species, average height, abundance, average coverage of herbs, shrubby plants (including tree seedlings) with $\mathrm{DBH}<3 \mathrm{~cm}$ and vines were recorded. The canopy cover was the average value visually estimated in the plot by three observers. If the difference among observations was $>10 \%$, the measurement process was repeated [40].

Table 1. Basic vegetation and soil characteristics of the established plots in the Songshan area in Beijing, China.

\begin{tabular}{|c|c|c|c|c|c|}
\hline Elevation & $800 \mathrm{~m}$ & $1000 \mathrm{~m}$ & $1200 \mathrm{~m}$ & $1400 \mathrm{~m}$ & $1600 \mathrm{~m}$ \\
\hline Slope $\left(^{\circ}\right)$ & $5-18$ & $16-25$ & $18-24$ & $22-26$ & $18-31$ \\
\hline Height (m) & $6.71(3.0,14.0)$ & $6.90(2.8,12.5)$ & $9.52(2.5,16.0)$ & $7.72(2.5,13.0)$ & $6.4(2.5,11.5)$ \\
\hline $\mathrm{DBH}(\mathrm{cm})$ & $10.25(4.0,28.2)$ & $10.60(3.4,40.0)$ & $11.69(3.2,34.0)$ & $13.2(4.0,36.0)$ & $11.1(4.5,49)$ \\
\hline Density (plants $/ \mathrm{hm}^{2}$ ) & $637(368,905)$ & $693(494,843)$ & $731(400,969)$ & $547(344,785)$ & $588(306,800)$ \\
\hline Canopy closure (\%) & $75-80$ & $55-80$ & $60-85$ & $40-80$ & 50-85 \\
\hline Soil type & Brown loam & Brown loam & Brown loam & Brown loam & Brown loam \\
\hline
\end{tabular}

Note: $\mathrm{DBH}$, diameter at breast height.

Soil samples were collected three times: in April (before germination), July (growing season) and October (after growing season) in 2019. Using the concentrated sampling method [41], soil from four $5 \mathrm{~cm}$ layers (to a depth of $20 \mathrm{~cm}$ ) was collected from 10 random sampling points $(10 \mathrm{~cm} \times 10 \mathrm{~cm})$ in each plot. Soil profiles were excavated at each sampling point, and garden shovels were used to collect soil from the side. Soil from the same depth was combined into one sample in a sealed plastic bag and transported to the greenhouse for drying on the same day. Three soil cores $(3 \mathrm{~cm}$ diameter, $20 \mathrm{~cm}$ depth) were randomly collected and mixed for the determination of the soil chemical properties, including total nitrogen (TN), available potassium (AP) available phosphorus (AK) and $\mathrm{pH}$. The Kjeldahl method, a potentiometer (S:W; 1:2.5) and a Mehlich 3 solution were used to measure these indicators. 


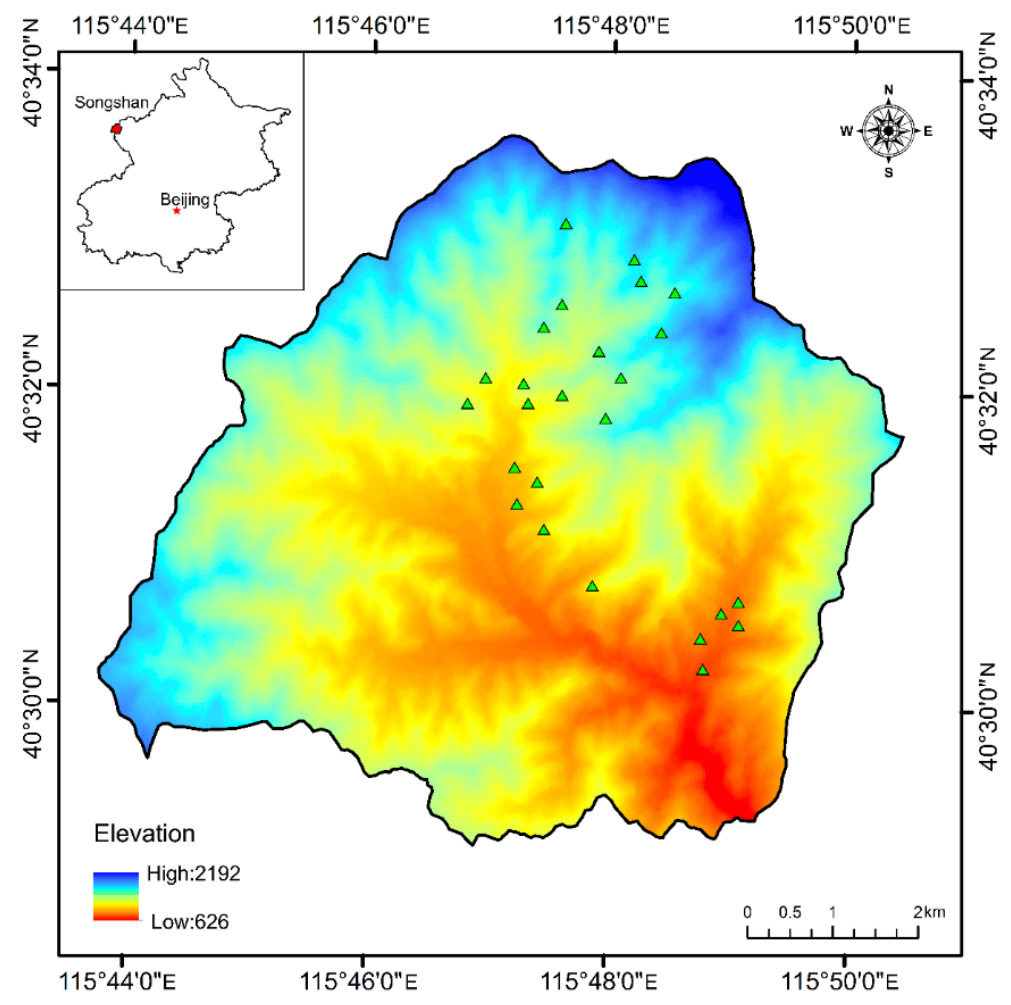

Figure 1. Sample plot locations in the Songshan area in Beijing, China.

Soil samples were placed in well-lit, well-ventilated and dry conditions for 10 days for direct exposure [18]. After the soil aggregates were crushed, the samples were passed through a $2 \mathrm{~mm}$ sieve to remove stones and plant debris [42]. The samples were then visually checked to ensure that large seeds were not present in the un-sieved samples. Species composition and quantity of available seeds in the samples were determined, using the direct germination method [43]. For this method, the soil samples were evenly spread (thickness $<2 \mathrm{~cm}$ ) on inactivated sand (sterilized at $140{ }^{\circ} \mathrm{C}$ for $24 \mathrm{~h}$ ) in a plastic germination pot $(25 \mathrm{~cm} \times 25 \mathrm{~cm} \times 5 \mathrm{~cm})$. Ten control germination pots containing only inactivated sand were placed amongst the germination samples to detect the influence of foreign seeds in the greenhouse.

The pots were regularly watered to ensure that the soil remained moist, and sample pots were visually checked every two days for the emergence of seeds. Any seedlings that were present were identified at the species level and recorded. Seedlings that were identifiable were immediately removed, and seedlings that were not identifiable were transferred to additional germination pots until they were identified. After two weeks of no activity in a pot (no new emergence of seeds), the soil samples were loosened to promote seed germination. After 180 days, when no new seeds had germinated for 30 consecutive days, the current experiments ended.

\subsection{Data Analysis}

Differences in species richness and relative abundance of the understory from different elevations were analyzed, using one-way analysis of variance (ANOVA) and the Tukey range test. Differences in density, species of soil seed banks among different elevations, seasons and layers were also analyzed, using multi-factor analysis of variance (ANOVA) and the Tukey range test. Before analysis, part of the data was logarithmically transformed to meet the normality and homogeneity of variance.

The Sørensen similarity coefficient was used to characterize the degree of similarity between the understory vegetation and the seed bank, calculated as follows:

$$
\mathrm{SC}=2 \mathrm{~W} /(\mathrm{a}+\mathrm{b})
$$


where $\mathrm{W}$ is the number of plant species co-existing in the seed bank and understory vegetation; a represents the number of soil seed bank species; and $b$ represents the number of understory vegetation species.

We used nonmetric multidimensional scaling (NMDS) to test seasonal differences in the similarity of the species composition between the seed banks and the surface vegetation at various elevations. The similarity matrix was calculated, using the Bray-Curtis coefficient, considered to be robust with respect to the ecological distance [44]. Furthermore, analysis of similarities (ANOSIM) was used to test the significance of the difference. NMDS and ANOMIS were performed in R 4.1.0 with vegan [45].

A structural equation model (SEM) was used to analyze the relationship between soil seed bank abundance and predictor variables (directly or indirectly), including the abundance of understory vegetation, the TN, AP, AK content, and soil $\mathrm{pH}[17,36]$. We used the retained variables in the best-fit regression model for the construction of the SEM. AMOS 24.0 was used to perform SEM as well as to transform all variables logarithmically, except for soil $\mathrm{pH}$, to improve normality.

\section{Results}

\subsection{Understory Vegetation Characteristics}

The vegetation survey recorded 145 species of understory plants, belonging to 56 families. A total of 70 species of shrubby plants from 27 families were identified (including tree seedlings and vines). Typical families of shrubby plants were Leguminosae, Saxifragaceae and Rosaceae. In addition, 75 species (29 families) of herbaceous plants were identified. Typical families of herbaceous plants included Asteraceae, Cyperaceae and Rosaceae. Among the identified plant species, the three most abundant families were Rosaceae (19 species), Asteraceae (16 species) and Liliaceae (9 species), accounting for $30.34 \%$ of species in all families.

Species richness ranged from 19 to 40 species among plots (Figure 2). Regardless of herbaceous plants, shrubby plants, or understory plants, the difference in species richness among the five elevation gradients was not significant $(p>0.05)$. The relative abundance of shrubby plants was notably lower than that of herbaceous plants at all plots, with no significant difference $(p>0.05)$ recorded among different elevations. However, the relative abundance of herbaceous plants $(F=7.453, p=0.001)$ and understory plants $(F=7.721, p=0.001)$ recorded a significant difference with an increase in elevation (Figure 2). The most abundant herbaceous species were Carex lanceolata, Duchesnea indica and Avena fatua, whilst Deutzia parviflora, Spiraea pubescens and Fraxinus rhynchophylla were the most abundant shrubby plants.
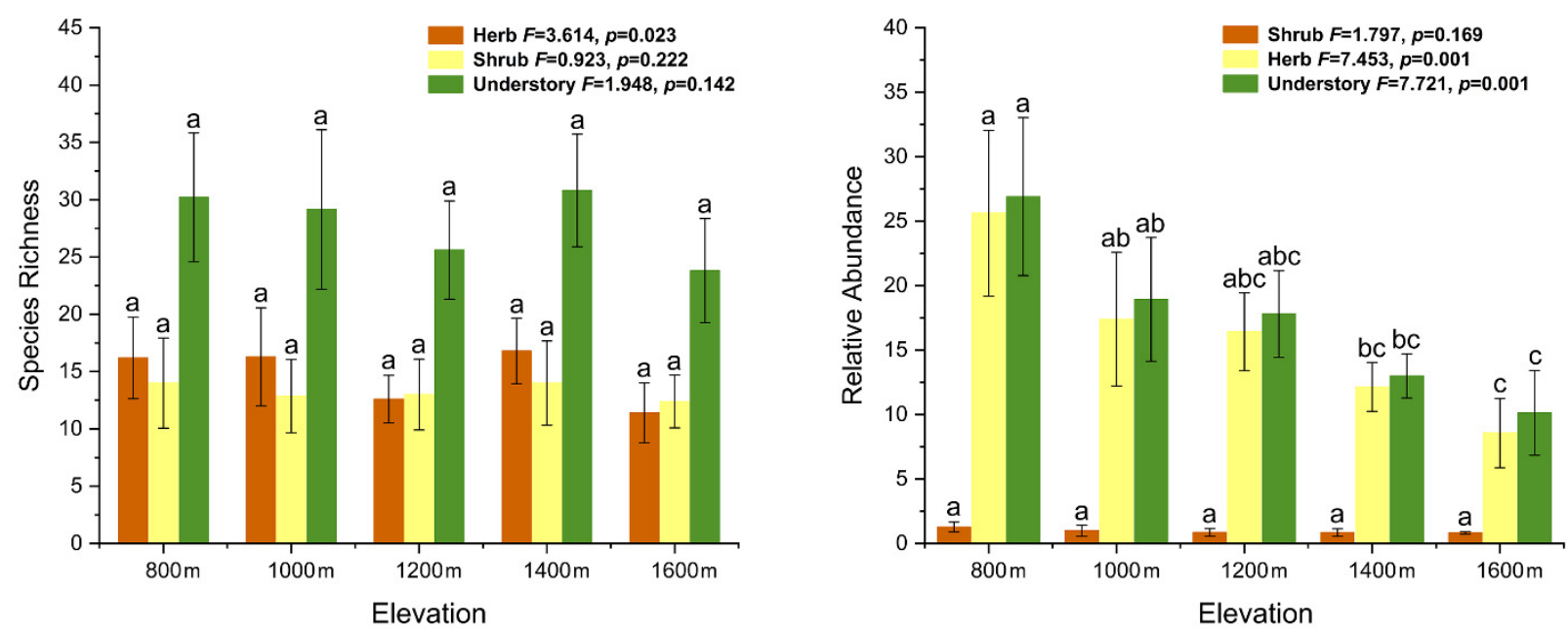

Figure 2. Species richness and relative abundance of understory plants at different elevations. Significant differences $(p<0.05)$ among different elevations were indicated by different lowercase letters (ANOVA, Tukey range test). Shrub, shrubby plants (including tree seedlings and vines); understory, shrub and herb. 


\subsection{Soil Seed Banks Characteristics}

As there were no contaminants recorded in the control trays during our experiment, all seedlings recorded during the germination test emerged from the soil seed bank. All seedlings that germinated were also successfully identified. During the experiment, 2361 seedlings germinated from samples collected in April; 1303 seedlings germinated from samples collected in July; and 1634 seedlings germinated from samples collected in October. In total, 116 species were recorded from 37 families. Asteraceae, Rosaceae and Poaceae were the dominant families. The seed bank density in the $0-20 \mathrm{~cm}$ soil layer for all samples varied from $1207 \pm 148$ to $4153 \pm 573$ seeds $\mathrm{m}^{-2}$. The maximum and minimum densities appeared in samples in April (800 m) and July (1600 m), respectively.

The seed bank species richness significantly changed with the elevation $(F=30.554$, $p<0.05)$ and season $(F=108.354, p<0.05)$. In terms of the seed density of the soil seed banks, changes in elevation $(F=27.228, p<0.05)$ and season $(F=138.513, p<0.05)$ were also significant. At all elevation levels, the maximum and minimum seed densities was recorded in April and July, respectively (Figure 3).
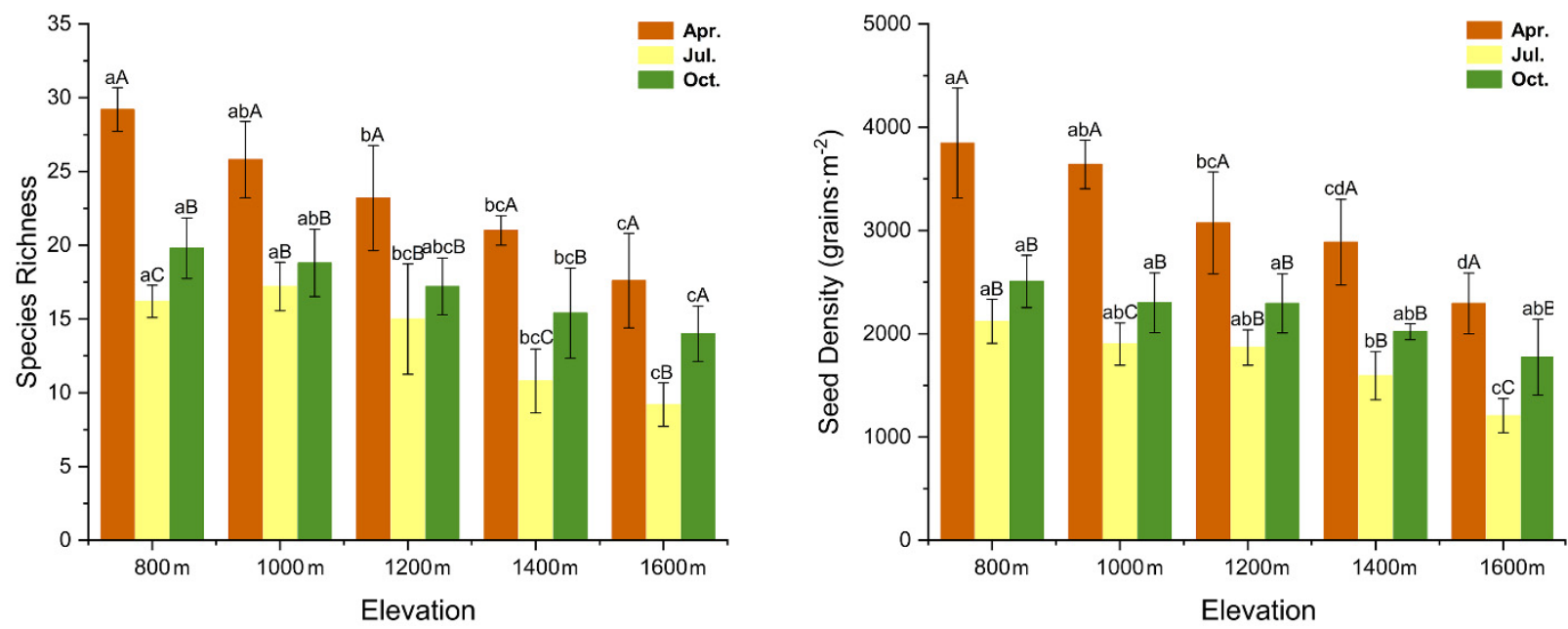

Figure 3. Species richness and seed density dynamics in the soil seed banks at different elevations and seasons. Different lowercase letters indicate significant differences $(p<0.05)$ among different elevations in the same season, and different uppercase letters indicate significant differences $(p<0.05)$ among different seasons at the same elevation (ANOVA and Tukey range test).

Overall, the proportion of species richness lifeform (Figure 4) in the soil seed bank recorded a slight variation with elevation and a significant variation with season. A similar trend was also recorded for the species richness proportion (Figure 5). In July, a greater quantity and variety of annual herbs were recorded in the seed bank than in either April or October. Additionally, the quantity and variety in the seed bank were different from those in the understory vegetation. For species richness, the proportion of trees and shrubs in the seed bank was lower than that of the understory vegetation, and the proportion of annual herbs significantly increased. In terms of quantity, the proportion of annual herbs and shrubs in the seed bank was higher than that of the understory vegetation, while the proportion of perennial herbs declined.

In addition, seeds were mainly located in the $0-5 \mathrm{~cm}$ soil layer, accounting for nearly $70 \%$ of the total seeds in the $0-20 \mathrm{~cm}$ soil layer (Figure 6). Soil seed bank density varied from $680 \pm 207$ to $2873 \pm 308$ seeds $\mathrm{m}^{-2}$ in the $0-5 \mathrm{~cm}$ soil layer, and from $13 \pm 16$ to $266 \pm 209$ seeds $\mathrm{m}^{-2}$ in the $5-10 \mathrm{~cm}$ soil layer. For some samples in the $10-20 \mathrm{~cm}$ soil layer, no seeds were recorded. 

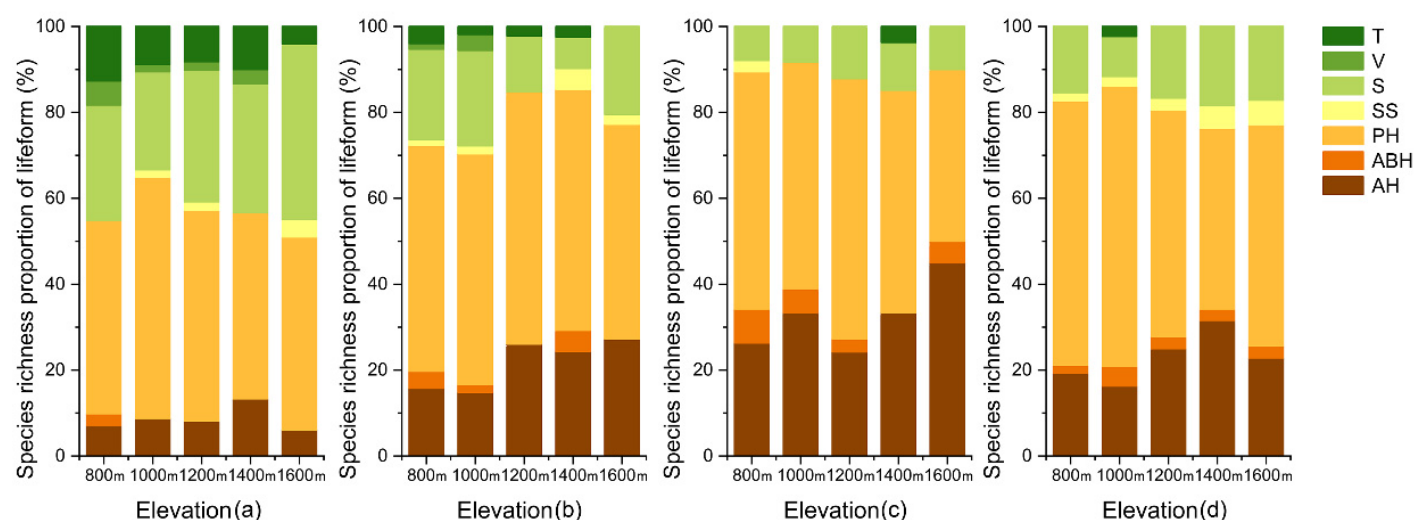

Figure 4. Species richness proportion of lifeform in understory vegetation (a) and soil seeds in April (b), July (c) and October (d) with elevation. $\mathrm{T}=$ tree, $\mathrm{V}=$ vine, $\mathrm{S}=$ shrub, $\mathrm{SS}=$ semi-shrub, $\mathrm{PH}=$ perennial herb, $\mathrm{ABH}=$ annual-biennial herb, $\mathrm{AH}=$ annual herb.
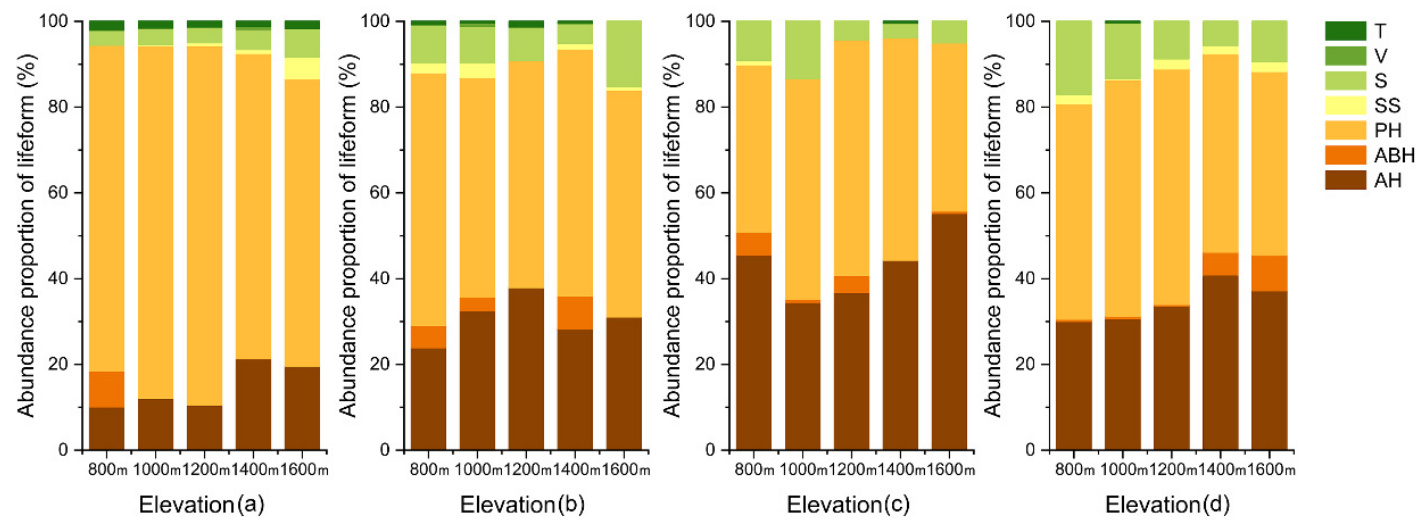

Figure 5. Abundance proportion of lifeform in understory vegetation (a) and soil seeds in April (b), July (c) and October (d) with elevation. $\mathrm{T}=$ tree, $\mathrm{V}=$ vine, $\mathrm{S}=$ shrub, $\mathrm{SS}=$ semi-shrub, $\mathrm{PH}=$ perennial herb, $\mathrm{ABH}=$ annual-biennial herb, $\mathrm{AH}=$ annual herb.
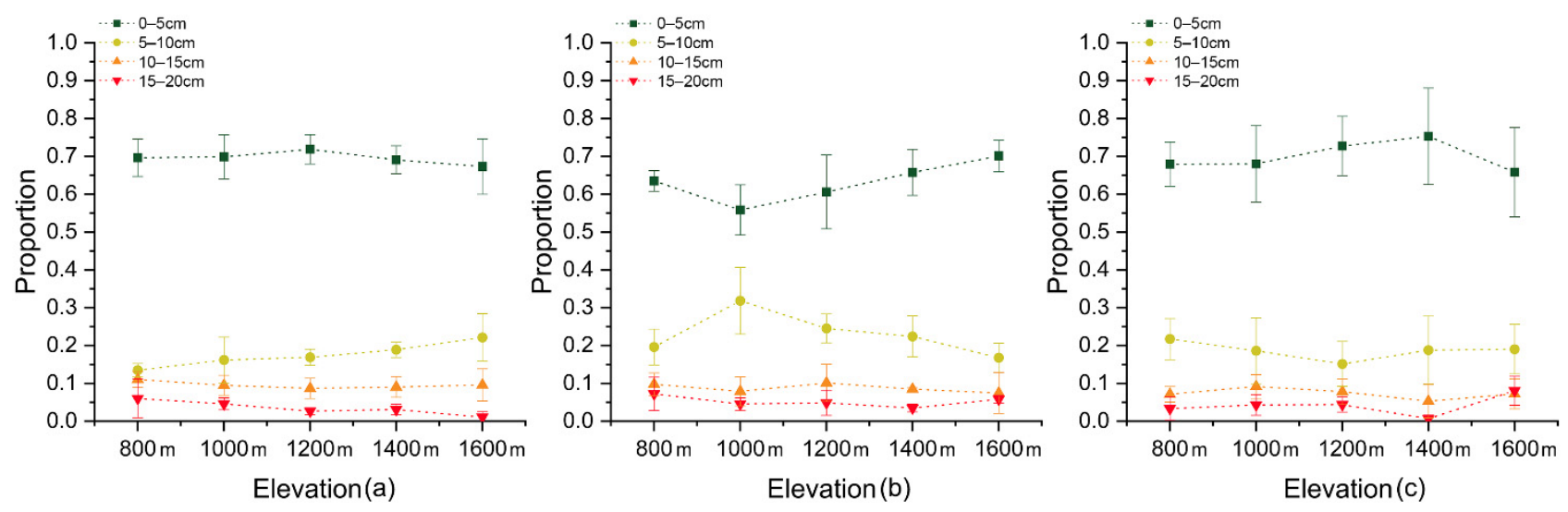

Figure 6. The proportion of seed bank density at different depths in the soil profile $(0-20 \mathrm{~cm})$ with elevation in April (a), July (b) and October (c).

\subsection{The Relationship of the Understory and Soil Seed Banks}

In the NMDS ordination (Figure 7), understory vegetation groups and seed bank groups were obviously separated. According to the ANOSIM test, we found that the species composition structure between the understory vegetation and soil seed bank significantly differed between seasons $(R=0.557, p=0.001)$. Differences in the species composition structure among the seed banks in each season were also smaller than the 
difference between seed banks in each season and understory vegetation. In addition, the similarity of the seed bank composition between April and October was less than that between April and July.

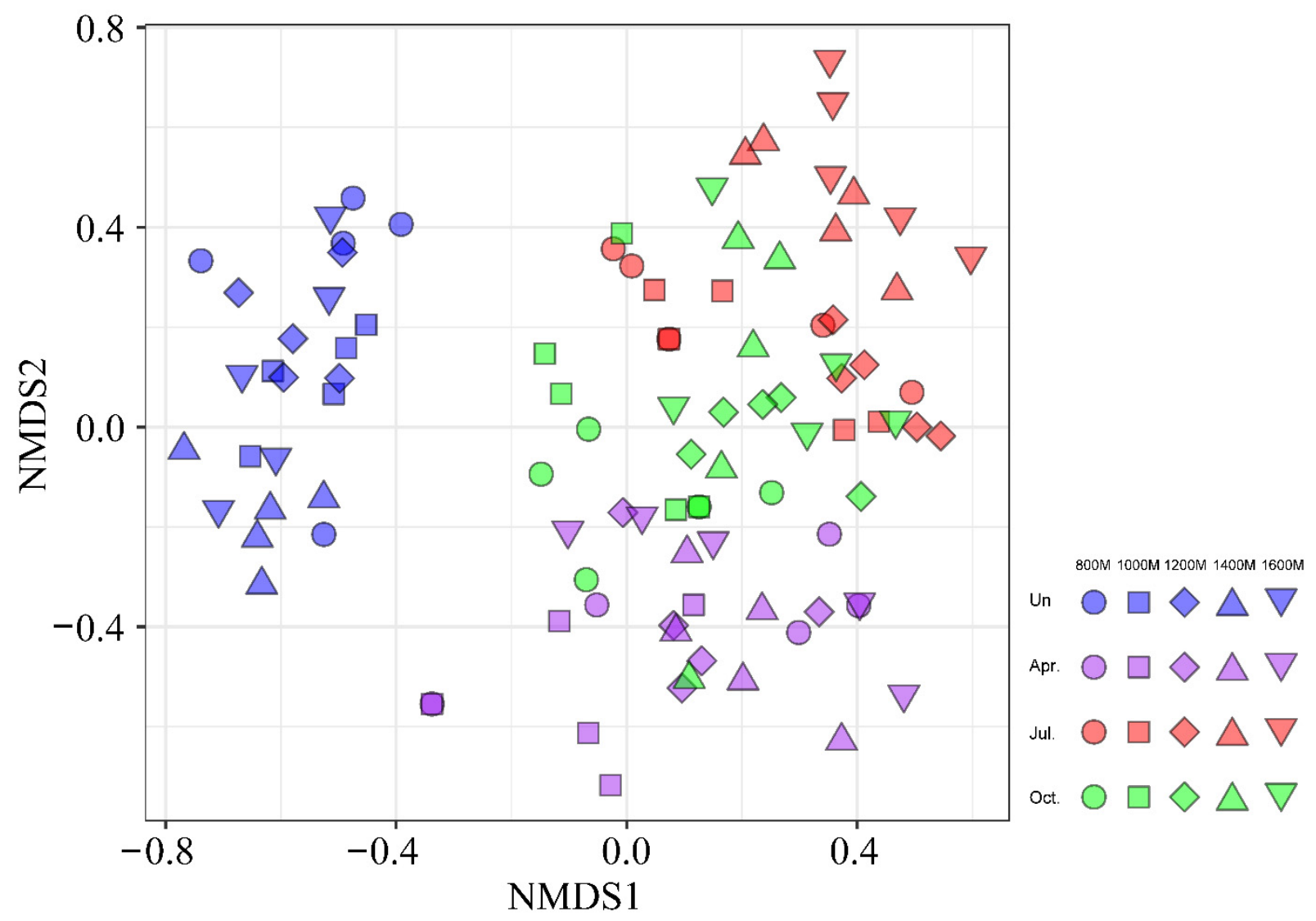

Figure 7. Two-dimensional nonmetric multidimensional scaling (NMDS) ordination of understory vegetation and seed banks along an elevational gradient $(800,1000,1200,1400$ and $1600 \mathrm{~m}$ ) in April, July and October (stress value $=0.1901)$. The marks change with the seasons, and the colors represent understory vegetation and seed banks during different seasons (Un-understory).

In the seed bank germination and vegetation survey, a total of 171 vascular plant species were recorded. Among these, 25 species were only found in the seed banks, accounting for $14.92 \%$ for the total. Nearly one-third (55) of species only appeared in the understory vegetation and were not found in the soil seed bank. Similarity of the species composition between the understory vegetation and the soil seed banks was low (Figure 8), and differences between seasons $(F=35.042, p<0.05)$ and elevation $(F=2.747, p<0.05)$ were significant. Similarity between the results was highest in April and lowest in July for all elevations. Species composition similarity between the understory vegetation and the soil seed banks recorded minor changes with elevation between April and July.

\subsection{Direct and Indirect Impacts of Elevation on the Soil Seed Bank}

In general, our data match had a good level of fit with the preset SEM (Figure 9). In the assessed response variables, elevation recorded the most dominant role, having a direct impact on the seed bank density $(p<0.05, \beta=-0.11)$ and understory vegetation abundance $(p<0.05, \beta=-0.61)$. As elevation increased, all indices decreased. In terms of soil nutrients, the AP $(p<0.001, \beta=-0.19)$ and $\operatorname{AK}(p<0.05, \beta=-0.20)$ contents were significantly affected by changes in elevation, indirectly affecting the seed bank density. TN was recorded to have a significantly negative effect $(p<0.001, \beta=-0.23$ ) on the seed bank density. 


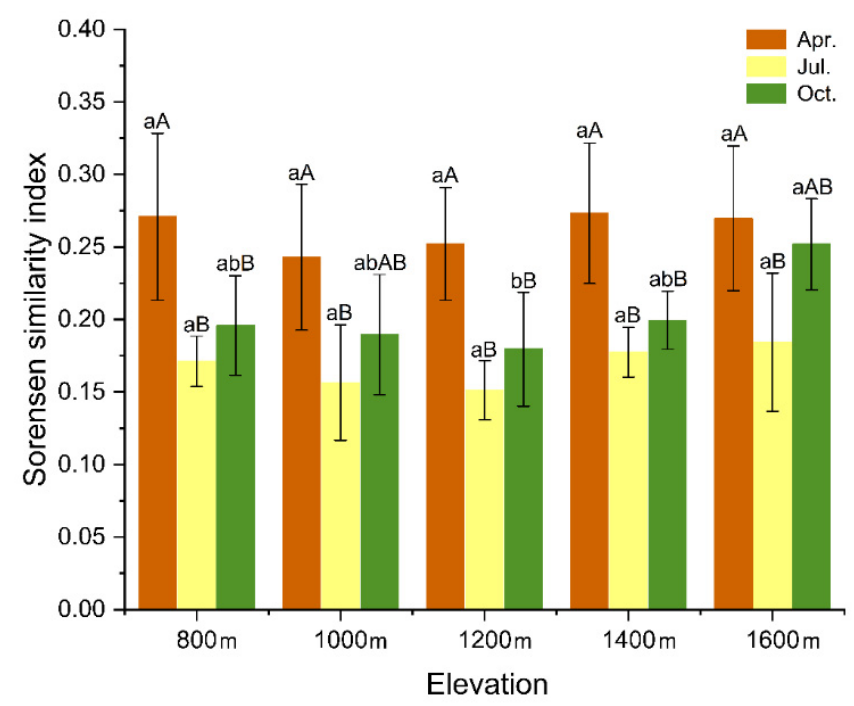

Figure 8. The Sørensen similarity index of different elevations and seasons. Different lowercase letters indicate significant differences $(p<0.05)$ among different elevations in the same season, and different uppercase letters indicate significant differences $(p<0.05)$ among different seasons at the same elevation (ANOVA and Tukey range test).

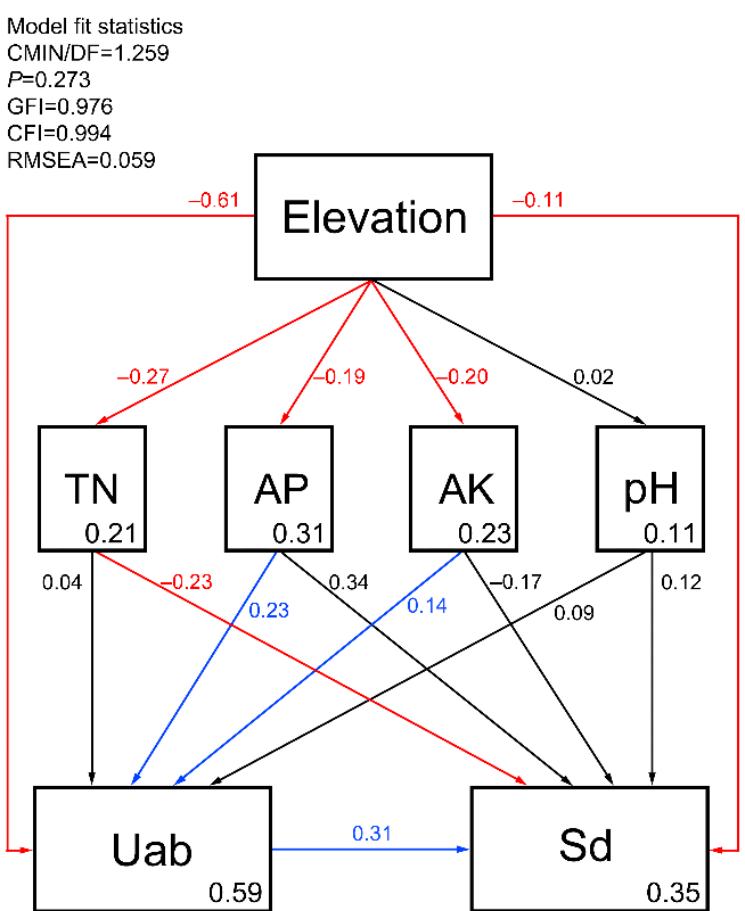

Figure 9. SEM showing the effects of the explanatory variables on species richness and density of the soil seed bank. A causal relationship is represented by arrows. Only the paths with significant influence $(p<0.05)$ are shown to simplify the graph. Multiple $\mathbf{R}^{2}$ are shown in the box of the respective response variable. Significant positive effects are indicated by blue lines and significant negative effects are indicated by red lines. Insignificant effects are indicated by black lines. TN-total nitrogen; $\mathrm{AP}$-available phosphorus; $\mathrm{AK}$-available potassium; Uab-abundance of understory vegetation; $\mathrm{Sd}$-soil seed banks density.

\section{Discussion}

\subsection{Characteristics of the Soil Seed Bank}

Seed bank density in the study area varied from $1207 \pm 148$ to $4153 \pm 573$ seeds $\mathrm{m}^{-2}$, similar to the results by Bossuyt and Honnay in European forests [46]. Compared with 
recent studies on grassland [18], wasteland [40], and tropical forests [31], our results are in the same order of magnitude; however, our average density is lower. It was proposed that this is due to the high canopy closure of natural secondary forests, which restricts understory growth and reduces seed production $[17,47]$.

As expected, density and species richness of the soil seed bank significantly decreased with elevation, corresponding with the conclusions of previous investigations $[17,18,48]$. It should be noted that seed bank density in the Red Sea region recorded a hump-shaped curve with an increase in elevation, while the trend was the same as our conclusion in the 800 1600 m elevation interval [19]. The decrease in seed bank abundance may be a result of the decline in richness of the aboveground vegetation [33]. As temperatures decline with elevation, a shortening of the growing and breeding season may have adverse effects on seed banks [49]. Murdoch et al.and Cavieres et al. also proposed that low temperatures are beneficial to seed bank maintenance and viability $[21,50]$. Low temperatures therefore increased persistent seed banks, having a cumulative effect on increasing seed bank density [45], a situation that generally occurs in high-cold and high-elevation areas [18]. In contrast, the temperature in our study area was higher and the temperature difference was smaller; thus, an increase in soil seed bank abundance due to low temperatures may not be reflected in our findings.

The results from our study indicated that density and species richness in the seed bank were highest in April and lowest in July, supporting our original hypothesis. The results also indicated that seasonal impacts on the seed bank had both positive and negative effects. The majority of plants produce seeds in the autumn, which are shed from this season to the following spring [43]. The persistence of a seed bank produced in the previous year ensures that the seed bank density and species richness will be, therefore, highest in the following spring [25]. In the summer, an increase in temperature and rainfall promotes soil microorganism activity, possibly resulting in seeds becoming moldy [51,52]. However, seed germination and predation might reduce the number of seeds in the seed bank [27], although higher seed predation probably occurs during the wet season [53]. Interestingly, studies recording similar results to our findings were typically undertaken in temperate and subtropical regions [27,28]; similar studies undertaken in the tropics recorded lower seed bank densities in the dry season (spring) than in other seasons [54,55]. We speculate that this finding is due to more species in the tropics producing seeds across multiple seasons, and more animal activities having an increased effect on the seasonal distribution of seed banks.

Apart from elevation and season, there were significant differences in the density of seed banks among soil layers at different depths. [9,18]. The vertical distribution of seeds in the soil was affected by seed size, rainfall and wildlife activities $[6,18,56]$. Previous investigations have shown that in areas where there is no human interference, most seeds occur in the upper $5 \mathrm{~cm}$ soil layer, gradually decreasing with depth $[57,58]$. Findings from our study recorded fewer seeds in the $10-20 \mathrm{~cm}$ soil layer (less than $20 \%$ ) than in the upper $10 \mathrm{~cm}$ layer; the litter layer on the ground and an increase in gravel content in the soil with depth may have also hindered seeds moving to deeper soil layers. In addition, almost all sampling points were located on a slope $\left(>15^{\circ}\right)$, resulting in the seed movement being along the slope rather than in a vertical direction under the action of external forces.

\subsection{The Relationship between Soil Seed Bank and Understory Vegetation}

In our results, the seed bank composition and understory vegetation significantly differed. The finding is consistent with previous results recording that species in the understory vegetation are dominated by shrubs and perennial herbs; seed banks were dominated by annual and perennial herbs [36]. In addition, the similarity between the seed bank and the understory vegetation was highest in spring (April) and lowest in summer (July). Differences in species composition were probably caused by seeds stored in the litter layer and sampling size limitations [59]. In the case of the emergent method, only components in the seed bank that could germinate under test conditions were counted, possibly resulting 
in errors in the results [60]. Typically, seeds from herb plants were abundant and relatively small, thus easily penetrating the soil surface to form seed banks [61]. In addition, due to asexual reproduction, some of the dominant perennial herbs contributed less to the seed bank than annual herbs [62,63]. In our study, C. lanceolata, Polygonatum odoratum and Agrimonia pilosa were widespread in the understory vegetation yet relatively rare in the seed bank; annual plants, such as Artemisia annua, Chenopodium album, and Avena fatua, produced a large number of seeds, which were identified during the germination test. By comparison, due to their shape and size, most shrub seeds were probably removed by animal activity [64]. In our results, the number of shrub seeds present in the seed bank in the different seasons only accounted for $7.40 \%-11.08 \%$ of total seeds, having a similar proportion of secondary forests in the Loess Plateau of China [36,60]. In addition, annual plant seeds were more likely to escape predation, resulting in an increase in their proportion in the persistent seed bank [65], possibly accounting for the higher proportion of annual herbs in the seed bank in July than in other seasons.

\subsection{The Influence of Elevation on the Soil Environment and Seed Banks}

Our results indicated that the soil TN, AP and AK contents decreased as elevation increased, similar to the results of Zou et al. [17]. Our results also indicated that seed bank abundance was directly affected by $\mathrm{TN}$ in the soil, and indirectly affected by AP and AK; therefore, the soil environment has an important influence on seed bank characteristics $[17,36,66]$. Soil AP and AK may be important factors affecting the abundance of understory vegetation and seed bank density [23]. Moreover, the higher TN content could increase soil microbial biomass [67], thereby exacerbating the presence of mildew on seeds in the soil seed bank and promoting seed germination [53], thus directly reducing the number of seed banks [36]. It was proposed that seed bank density is significantly affected by $\mathrm{pH}$; the results from our investigation did not support this idea $[68,69]$. We speculate that our findings may be related to the existence of the same soil type in our samples, and thus, $\mathrm{pH}$ variation was relatively small [36]. In addition, existing studies have shown that factors such as metal cations and moisture could also cause changes in the characteristics of the seed bank $[36,70]$, providing a possible area to investigate in future studies.

\subsection{Ecological Restoration Potential of Seed Banks}

In our results, herbs accounted for more than $80 \%$ of the total seed bank, with plants from 61 to 75 species. Dominant annual herbs, such as A. fatua, C. album and A. annua, and dominant perennial herbs, such as $D$. indica, $C$. chanetii and $A$. mongolica, not only widely existed in the seed bank, but they also produced a large number of seeds after maturity. As efficient pioneer species, annual herbs can germinate and complete their lifecycle in a short time period [71]. In contrast, development and biomass accumulation of perennial plants is relatively slow; however, many of these plants can reproduce vegetatively [72], thereby enhancing ecological stability. Seeds present in the topsoil can support the restoration of the disturbed area in the direction of the original community [73]. When a construction project needs to remove topsoil, this soil can be used as a substrate and seed source for ecological restoration [74]. Apart from this, fungal and bacterial symbionts are beneficial to the growth of indigenous plant species [16]. In addition, tubers, corms, rhizomes and root fragments as the bud bank can also serve as sources of seedlings [75]. It has been shown that when topsoil is used for ecological restoration, the main source of woody plants is root fragments rather than seeds [76]. This occurrence may, therefore, compensate for the complementation of the seed composition in the topsoil, thereby improving the diversity and stability of the community. In summary, from the perspective of quantity and diversity, ecological restoration using topsoil in the study area can achieve good results. As the characteristics of the seed bank vary greatly between different seasons and elevations, their impact should be considered in relation to specific restoration work. 


\section{Conclusions}

Results from our investigation indicate that elevation and season are important factors affecting seed banks in the rocky mountainous area of North China. The increase in elevation has an impact on the composition of the understory vegetation and some soil nutrients, directly or indirectly resulting in a decrease in species abundance and variety in the seed bank. Changes in species composition and abundance in the seed bank caused by seasonal changes are also important. Our findings indicate that the soil seed bank in this area has a strong potential for ecological restoration. It is also important to consider the influence of season and elevation during topsoil collection and utilization. Future research will examine the recovery abilities of topsoil as an ecological restoration material, verifying its use in remediation processes.

Author Contributions: C.X. and T.Z. conceived and designed the experiments; C.X. and J.W. performed the experiments; C.X. analyzed the data; J.Y. contributed reagents/materials/analysis tools; C.X. wrote the paper. All authors have read and agreed to the published version of the manuscript.

Funding: This study was funded by the Monitoring and Evaluation of Ecological Protection Works of Competition Zone in the Beijing Mountain Area of 2022 Olympics Winter Games (Z181100005318004) and Comprehensive Background Investigation and Evaluation of Ecological Environment Protection in Beijing 2022 Yanqing Competition Zone (2016HXFWBHQZZX002).

Institutional Review Board Statement: Not applicable.

Informed Consent Statement: Not applicable.

Data Availability Statement: Not applicable.

Acknowledgments: We gratefully acknowledge all those who have participated in the field investigation and laboratory test. We are also grateful to Yachao Wang for species identification in the field and the greenhouse, and to Dedong Liang for coordinating the work and providing the study site.

Conflicts of Interest: The authors declare no conflict of interest.

\section{References}

1. Yang, L.; Jia, K.; Liang, S.; Liu, M.; Wei, X.; Yao, Y.; Zhang, X.; Liu, D. Spatio-temporal analysis and uncertainty of fractional vegetation cover change over northern China during 2001-2012 based on multiple vegetation data sets. Remote Sens. 2018, 10, 549. [CrossRef]

2. Wang, Z.; Cao, J. Research advances in vegetation restoration and its ecological effects in earth-rock mountain areas of North China. Chin. J. Eco-Agric. 2019, 27, 1319-1331.

3. Cao, S. Why large-scale afforestation efforts in China have failed to solve the desertification problem. Environ. Sci. Technol. 2008, 42, 1826-1831. [CrossRef] [PubMed]

4. Chu, X.; Zhan, J.; Li, Z.; Zhang, F.; Qi, W. Assessment on forest carbon sequestration in the Three-North Shelterbelt Program region, China. J. Clean. Prod. 2019, 214, 382-389. [CrossRef]

5. Simpson, R.L.; Leck, M.A.; Parker, V.T. Ecology of Soil Seed Bank; Academic Press: San Diego, CA, USA, 1989; pp. 3-8.

6. Garwood, N.C. Tropical Soil Seed Banks: A Review. In Ecology of Soil Seed Banks; Simpson, R.L., Leck, M.A., Parker, V.T., Eds.; Academic Press: San Diego, CA, USA, 1989; pp. 149-209.

7. Enright, N.J.; Fontaine, J.B.; Lamont, B.B.; Miller, B.P.; Westcott, V.C. Resistance and resilience to changing climate and fire regime depend on plant functional traits. J. Ecol. 2014, 102, 1572-1581. [CrossRef]

8. Erfanzadeh, R.; Kahnuj, S.H.H.; Azarnivand, H.; Pétillon, J. Comparison of soil seed banks of habitats distributed along an altitudinal gradient in northern Iran. Flora Morphol. Distrib. Funct. Ecol. Plants 2013, 208, 312-320. [CrossRef]

9. Pereira-Diniz, S.; Ranal, M.A. Germinable soil seed bank of a gallery forest in Brazilian Cerrado. Plant Ecol. 2006, 183, 337-348. [CrossRef]

10. Bakker, J.P.; Berendse, F. Constraints in the restoration of ecological diversity in grassland and heathland communities. Trends Ecol. Evol. 1999, 14, 63-68. [CrossRef]

11. Thompson, K. The functional ecology of soil seed banks. In Seeds: The Ecology of Regeneration in Plant Communities; Fenner, M., Ed.; CABI: London, UK, 2000; pp. 215-235.

12. Golos, P.J. Restoring Vegetation on Waste Rock Dumps at the Telfer Mine Site in Australia's Great Sandy Desert: Topsoil Management and Plant Establishment. Ph. D Thesis, The University of Western Australia, Crawley, Australia, 2013.

13. Scoles-Sciulla, S.J; Defalco, L.A. Seed reserves diluted during surface soil reclamation in eastern Mojave Desert. Arid. Soil. Res. Rehabil. 2009, 23, 1-13. [CrossRef] 
14. Sun, Y.; Yan, C.; Wei, Y.; Xu, H.; Yao, Y. Influence of topsoil addition on species diversity and aboveground biomass of plant community on the damaged mined land in Altay, China. Fresenius Environ. Bull. 2017, 26, 2214-2220.

15. Martínez-Ruiz, C.; Marrs, R.H. Some factors affecting successional change on uranium mine wastes: Insights for ecological restoration. Appl. Veg. Sci. 2007, 10, 333-342. [CrossRef]

16. Jasper, D.A. Beneficial soil microorganisms of the Jarrah forest and their recovery in bauxite mine restoration in Southwestern Australia. Restor. Ecol. 2007, 15, 74-84. [CrossRef]

17. Zou, C.; Martini, F.; Xia, S.W.; Castillo-Diaz, D.; Goodale, U.M. Elevation and micro environmental conditions directly and indirectly influence forests' soil seed bank communities. Glob. Ecol. Conserv. 2021, 26, e01443. [CrossRef]

18. Ma, M.; Zhou, X.; Wang, G.; Ma, Z.; Du, G. Seasonal dynamics in alpine meadow seed banks along an altitudinal gradient on the Tibetan Plateau. Plant Soil 2010, 336, 291-302. [CrossRef]

19. Hegazy, A.K.; Hammouda, O.; Lovett-Doust, J.; Gomaa, N.H. Variations of the germinable soil seed bank along the altitudinal gradient in the northwestern Red Sea region. Acta Ecol. Sin. 2009, 29, 20-29. [CrossRef]

20. Mcgraw, J.B. The role of buried viable seeds in arctic and alpine plant communities. In Ecology of Soil Seed Banks; Simpson, R.L., Leck, M.A., Parker, V.T., Eds.; Academic Press: San Diego, CA, USA, 1989; pp. 91-105.

21. Murdoch, A.J.; Ellis, R.M. Dormancy, viability and longevity. In Seeds: The Ecology of Regeneration in Plant Communities; Fenner, M., Ed.; CABI: London, UK, 2000; pp. 183-214.

22. Jalili, A.; Hamzeh'ee, B.; Asri, Y.; Shirvany, A.; Yazdani, S.; Khoshnevis, M.; Zarrinkamar, F.; Ghahramani, M.A.; Safavi, R.; Shaw, S.; et al. Soil seed banks in the arasbaran protected area of iran and their significance for conservation management. Biol. Conserv. 2003, 109, 425-431. [CrossRef]

23. Vitousek, P.M.; Porder, S.; Houlton, B.Z.; Chadwick, O.A. Terrestrial phosphorus limitation: Mechanisms, implications, and nitrogen-phosphorus interactions. Ecol. Appl. 2010, 20, 5-15. [CrossRef]

24. Ediriweera, S.; Ashton, B.M.P.; Ashton, M.S. Variation in canopy structure, light and soil nutrition across elevation of a sri lankan tropical rain forest. For. Ecol. Manag. 2008, 256, 1339-1349. [CrossRef]

25. Russi, L.; Cocks, P.S.; Robert, E.H. Seed bank dynamics in a Mediterranean grassland. J. Appl. Ecol. 1992, 29, 763-771. [CrossRef]

26. Mayor, M.D.; Bóo, R.M.; Peláez, D.V.; Elıa, O.R. Seasonal variation of the soil seed bank of grasses in central Argentina as related to grazing and shrub cover. J. Arid Environ. 2003, 29, 467-477. [CrossRef]

27. Onaindia, M.; Amezaga, I. Seasonal variation in the seed banks of naive woodland and coniferous plantations in Northern Spain. For. Ecol. Manag. 2008, 126, 163-172. [CrossRef]

28. Shen, Y.; Liu, W.; Cao, M.; Liu, Y.H. Seasonal variation in density and species richness of soil seed-banks in karst forests and degraded vegetation in central Yunnan, SW China. Seed Sci. Res. 2007, 17, 99-107. [CrossRef]

29. Ranal, M.A. Soil spore bank of ferns in a gallery forest of the ecological station of Panga, Uberlndia, MG, Brazil. Am. Fern. J. 2003, 93, 97-115. [CrossRef]

30. Erfanzadeh, R.; Hazhir, S.; Jafari, M. Effect of cushion plants on soil seed bank in overgrazed semi-arid regions. Land Degrad. Dev. 2020, 31, 990-1000. [CrossRef]

31. Luo, X.; Cao, M.; Zhang, M. Soil seed banks along elevational gradients in tropical, subtropical and subalpine forests in Yunnan Province, southwest China. Plant Divers. 2017, 39, 273-286. [CrossRef]

32. Rice, K.J. Impacts of seed banks on grassland community structure and population dynamics. In Ecology of Soil Seed Banks; Simpson, R.L., Leck, M.A., Parker, V.T., Eds.; Academic Press: San Diego, CA, USA, 1989; pp. 212-230.

33. Ortega, M.; Levassor, C.; Peco, B. Seasonal dynamics of Mediterranean pasture seed banks along environmental gradients. J. Biogeogr. 1997, 24, 177-195. [CrossRef]

34. Amiaud, B.; Touzard, B. The relationships between soil seed bank aboveground vegetation and disturbances in old embanked marshlands of Western France. Flora-Morphol. Distrib. Funct. Ecol. Plants 2004, 199, 25-35. [CrossRef]

35. Hopfensperger, K.N. A review of similarity between seed bank and standing vegetation across ecosystems. OIKOS 2007, 116, 1438-1448. [CrossRef]

36. Zhao, Y.; Li, M.; Deng, J.; Wang, B. Afforestation affects soil seed banks by altering soil properties and understory plants on the eastern loess plateau, China. Ecol. Indic. 2021, 126, 107670. [CrossRef]

37. Wang, J.; Zhu, B.; Wang, T. Characteristics of restoration of natural herbaceous vegetation of typical water-level fluctuation zone after flooding in the three gorges reservoir area. Resour. Environ. Yangtze Basin 2011, 20, 603-610.

38. Csontos, P.; Tamás, J. Comparisons of soil seed bank classification systems. Seed Sci. Res. 2003, 13, 101-111. [CrossRef]

39. Mu, X.; He, L.; Wu, J.; Jiang, W.; Zhang, Z. Analyses on distribution and species composition of wild seed plant in Beijing Songshan National Nature Reserve. J. Plant Resour. Environ. 2014, 23, 94-101.

40. Kou, M.; Garcia-Fayos, P.; Jiao, H. The effect of Robinia pseudoacacia afforestation on soil and vegetation properties in the loess plateau (China): A chronosequence approach. For. Ecol. Manag. 2016, 375, 146-158. [CrossRef]

41. Heerdt, G.N.J.; Verweij, G.L.; Bekker, R.M.; Bakker, J.P. An improved method for seed-bank analysis: Seedling emergence after removing the soil by sieving. Funct. Ecol. 1996, 10, 144-151. [CrossRef]

42. Funes, G.; Basconcelo, S.; Diaz, S.; Cabido, M. Seed size and shape are good predictors of seed persistence in soil in temperate mountain grasslands of Argentina. Seed Sci. Res. 1999, 9, 341-345. [CrossRef]

43. Thompson, K.; Grime, J.P. Seasonal variation in the seed banks of herbaceous species in ten contrasting habitats. J. Ecol. 1979, 67, 893-921. [CrossRef] 
44. Faith, D.P.; Minchin, P.R.; Belbin, L. Compositional dissimilarity as a robust measure of ecological distance. Vegetatio 1987, 69, 57-68. [CrossRef]

45. Oksanen, J.; Blanche, F.G.; Friendly, M. Vegan: Community Ecology Package; R Package Version 2.5. 2020. Available online: https:/ /CRAN.R-project.org/package=vegan (accessed on 28 November 2020).

46. Bossuyt, B.; Honnay, O. Can the seed bank be used for ecological restoration? An overview of seed bank characteristics in European communities. J. Veg. Sci. 2008, 19, 875-884. [CrossRef]

47. Ida, T.Y.; Gaku, K. Timing of canopy closure influences carbon translocation and seed production of an understorey herb, trillium apetalon (trilliaceae). Ann. Bot. 2008, 101, 435-446. [CrossRef] [PubMed]

48. Cummins, R.P.; Miller, G.R. Altitudinal gradients in seed dynamics of Calluna vulgaris in eastern Scotland. J. Veg. Sci. 2002, 13, 859-866. [CrossRef]

49. Thompson, K. The functional ecology of seed banks. In Seeds: The Ecology of Regeneration in Plant Communities; Fenner, M., Ed.; CABI: London, UK, 2000; pp. 231-258.

50. Cavieres, L.A.; Mary, T.K. Persistent soil seed banks in Phacelia secunda (hydrophyllaceae): Experimental detection of variation along an altitudinal gradient in the andes of central chile (33 S). J. Ecol. 2001, 89, 31-39. [CrossRef]

51. Funes, G.; Basconcelo, S.; Diaz, S.; Cabido, M. Seed bank dynamics in tall-tussock grasslands along an altitudinal gradient. J. Veg. 2003, 14, 253-258. [CrossRef]

52. Zhang, X.B.; Wang, R.J.; Shangguan, Z.P. Dynamics of seed rain and soil seed bank in Pinus tabuliformis Carr. Forests in eroded hilly loess regions of the Loess Plateau in China. Acta Ecol. Sin. 2009, 29, 1877-1884.

53. Fleury, M.; Rodrigues, R.R.; do Couto, H.T.Z.; Galetti, M. Seasonal variation in the fate of seeds under contrasting logging regimes. PLOS ONE 2014, 9, e90060.

54. Dalling, J.W.; Swaine, M.D.; Garwood, N.C. Soil seed bank community dynamics in seasonally moist lowland tropical forest, Panama. J. Trop. Ecol. 1997, 13, 659-680. [CrossRef]

55. Dupuy, J.M.; Chazdon, R.L. Long-term effects of forest regrowth and selective logging on the seed bank of Tropical Forests in NE Costa Rica. Biotropica 1998, 30, 223-237. [CrossRef]

56. Marone, L.; Rossi, B.E.; Lopez, D.C.J. Granivore impact on soil seed reserves in the Central Monte Desert, Argentina. Funct. Ecol. 1998, 12, 640-645. [CrossRef]

57. Guo, Q.; Rundel, P.W.; Goodall, D.W. Horizontal and vertical distribution of desert seed banks: Patterns, causes, and implications. J. Arid Environ. 1998, 38, 465-478. [CrossRef]

58. Demel, T. Soil seed bank at an abandoned Afromontane arable site. Feddes Repert. 2008, 109, 161-174. [CrossRef]

59. Cheng, J.M.; Cheng, J.; Shao, H.; Zhao, L. Soil seed banks and forest succession direction reflect soil quality in Ziwuling mountain, loess plateau, China. Clean-Soil Air Water 2012, 40, 140-147. [CrossRef]

60. Wang, N.; Jiao, J.Y.; Jia, Y.F.; Bai, W.J.; Zhang, Z.G. Germinable soil seed banks and the restoration potential of abandoned cropland on the Chinese hilly-gullied loess plateau. Environ. Manag. 2010, 46, 367-377. [CrossRef]

61. Douh, C.; Daïnou, K.; Loumeto, J.J.; Moutsambote, J.M.; Fayolle, A.; Tosso, F.; Forni, E.; Gourlet-Fleury, S.; Doucet, J.L. Soil seed bank characteristics in two central African forest types and implications for forest restoration. For. Ecol. Manag. 2018, 409, 766-776. [CrossRef]

62. Edwards, G.R.; Crawley, M.J. Herbivores, seed banks and seedling recruitment in mesic grassland. J. Ecol. 1999, 87, 423-435. [CrossRef]

63. Ma, M.; Du, G.; Zhou, X. Role of the soil seed bank during succession in a subalpine meadow on the Tibetan Plateau. Arct. Antarct. Alp. Res. 2009, 41, 469-477. [CrossRef]

64. Gómez, J.M. Bigger is not always better: Conflicting selective pressures on seed size in Quercus ilex. Evolution 2004, 58, 71-80. [CrossRef]

65. Peco, B.; Traba, J.; Levassor, C.; Sánchez, A.M.; Azcárate, F.M. Seed size, shape and persistence in dry Mediterranean grass and scrublands. Seed Sci. Res. 2003, 13, 87-95. [CrossRef]

66. Haight, J.D.; Reed, R.C.; Faist, A.M. Seed bank community and soil texture relationships in a cold desert. J. Arid Environ. 2019, 164, 46-52. [CrossRef]

67. Ma, M.; Colins, S.; Du, G. Direct and indirect effects of temperature and precipitation on alpine seed banks in the Tibetan Plateau. Ecol. Appl. 2020, 30, e02096. [CrossRef]

68. De Keersmaeker, L.; Martens, L.; Verheyen, K.; Hermy, M.; De Schrijver, A.; Lust, N. Impact of soil fertility and insolation on diversity of herbaceous woodland species colonizing afforestations in Muizen forest (Belgium). For. Ecol. Manag. 2004, 188, 291-304. [CrossRef]

69. Erenler, H.E.; Ashton, P.A.; Gillman, M.P.; Ollerton, J. Factors determining species richness of soil seed banks in lowland ancient woodlands. Biodivers. Conserv. 2010, 19, 1631-1648. [CrossRef]

70. Fan, Z.L.; Mo, L.Y.; Chen, T.B.; Zhai, L.M.; Lei, M.; Huang, A.Q.; Li, H. Accumulation of Cu, Mn and Zn in plants grown in areas near three abandoned mines in Guangxi and the discovery of potential Mn-hyperaccumulators. Geogr. Res. 2007, 1, 125-131.

71. Rapport, D.J.; Whitford, W.G. How ecosystems respond to stress: Common properties of arid and aquatic systems. BioScience 1999, 49, 193-203. [CrossRef]

72. Aires, S.S.; Sato, M.N.; Miranda, H.S. Seed characterization and direct sowing of native grass species as a management tool. Grass Amd. Forage Sci. 2014, 69, 470-478. [CrossRef] 
73. Rokich, D.P.; Dixon, K.W.; Sivasithamparam, K.; Meney, K.A. Topsoil handling and storage effects on woodland restoration in Western Australia. Restor. Ecol. 2000, 8, 196-208. [CrossRef]

74. Tacey, W.H.; Glossop, B.L. Assessment of topsoil handling techniques for restoration of sites mined for bauxite within the Jarrah Forest of Western Australia. J. Appl. Ecol. 1980, 17, 195-201. [CrossRef]

75. Tozer, M.G.; Mackenzie, B.; Simpson, C.C. An application of plant functional types for predicting restoration outcomes. Restor. Ecol. 2012, 20, 730-739. [CrossRef]

76. Ferreira, M.C.; Walter, B.M.T.; Vieira, D.L.M. Topsoil translocation for Brazilian savanna restoration: Propagation of herbs, shrubs, and trees. Restor. Ecol. 2015, 23, 723-728. [CrossRef] 